\title{
TERAPI ISOTRETINOIN ORAL PADA PSORIASIS ERITRODERMA YANG MENYERUPAI IKTIOSIS HEREDITER: LAPORAN KASUS DAN TELAAH PUSTAKA
}

\author{
Malvan, Sunardi Radiono, Erdina, Retno Danarti
}

Departemen Dermatologi dan Venereologi, Fakultas Kedokteran, Kesehatan Masyarakat, dan Keperawatan Universitas Gadjah Mada/RSUP dr. Sardjito, Yogyakarta

\begin{abstract}
ABSTRAK
Psoriasis eritroderma pada anak merupakan varian psoriasis yang paling jarang. Kelainan ini ditandai secara khas oleh eritema pada seluruh tubuh dengan skuama putih berlapis tebal, disertai ektropion, eklabium, dan onikodistrofi. Manifestasi kulit tersebut sering keliru didiagnosis sebagai iktiosis herediter. Salah satu pilihan terapi sistemik psoriasis eritroderma adalah isotretinoin oral. Obat tersebut bekerja dengan cara menghambat dan mengurangi diferensiasi dan hiperproliferasi keratinosit, serta mencegah infiltrasi sel radang di kulit pada psoriasis. Perlu diperhatikan bahwa isotretinoin dapat menimbulkan efek samping yang berakibat fatal.

Pada kasus dilaporkan seorang anak perempuan usia 4,5 tahun dengan kulit seluruh tubuh eritematosa ditutupi skuama putih, melekat, berlapis tebal, disertai ektropion dan eklabium, menyerupai iktiosis herediter. Dengan ditemukannya mikroabses Munro pada pemeriksaan histopatologi, pasien didiagnosis sebagai psoriasis eritroderma. Terapi dengan isotretinoin oral memberikan hasil yang memuaskan, namun menimbulkan efek samping berupa trombositopenia. Perlu pemantauan ketat dan evaluasi laboratorium rutin pada pemberian isotretinoin oral untuk psoriasis eritroderma anak, sehingga apabila ditemukan kelainan dapat segera dilakukan tatalaksana yang tepat.

Kata kunci: psoriasis eritroderma, mikroabses Munro, isotretinoin oral, trombositopenia.
\end{abstract}

\section{ORAL ISOTRETINOIN THERAPY FOR PSORIATIC ERYTHRODERMA MIMICKING HEREDITARY ICHTHYOSIS: CASE REPORT AND LITERATURE REVIEW}

\section{Korespondensi:}

Gedung Radiopoetro Lantai 3,

J1 Farmako, Sekip, Yogyakarta 55281

Telp: 0274560700

Email: danarti@ugm.ac.id

\begin{abstract}
Psoriatic erythroderma in children is the rarest psoriasis variant. Its patognomonic clinical features consist of whole body erythematous with white thick scales, ectropion, eclabium, and onychodystrophy. Those skin manisfestasions are often misdiagnosed as a hereditary ichthyosis. One choice of systemic therapies for psoriatic erythroderma is oral isotretinoin which exerts their therapeutic effect by modulating the three major pathogenic features of psoriasis, i.e. disturbed keratinocyte differentiation, keratinocyte hyperproliferation, and infiltration of tissue by inflammatory cells. Despite of that effectivity, it is critical to understand its fatal side effects.

We report a 4-year-old girl with whole body redness, covered with white thick scales, accompanied with ectropion and eclabium, similar to the clinical features of hereditary ichthyosis. Histopathological examination showed Munro microabscess, confirming the diagnosis of psoriatic erythroderma. Isotretinoin therapy gave satisfactory result, but showed thrombocytopenia. We strongly suggest that for oral isotretinoin treatment for children with psoriatic erythroderma, intensive monitoring and routine laboratorium evaluation is needed for early detection of its side effects.
\end{abstract}

Keywords: psoriatic erythroderma, oral isotretinoin, Munro microabscess, thrombocytopenia 


\section{PENDAHULUAN}

Psoriasis merupakan penyakit inflamasi autoimun kronik dengan spektrum klinis yang luas. Awitan penyakit ini dapat timbul pada usia berapapun termasuk usia anak. ${ }^{1,2}$ Prevalensi psoriasis pada anak diperkirakan 1-3\% dari seluruh populasi di dunia. ${ }^{2,3}$ Terdapat beberapa varian psoriasis yang dapat muncul pada usia anak. ${ }^{3}$ Psoriasis eritroderma merupakan varian psoriasis anak yang paling jarang terjadi. Manifestasi klinis berupa eritema dengan skuama putih berlapis disertai ektropion, eklabium, dan kerusakan kuku, yang sering keliru didiagnosis sebagai iktiosis herediter. Pada kasus seperti ini, pemeriksaan histopatologik berperan penting dalam menegakkan diagnosis psoriasis eritroderma. ${ }^{1-3}$

Untuk menentukan terapi poriasis pada anak, harus diperhatikan tumbuh kembang anak. Terapi sistemik diperlukan pada kasus kronis dan derajat psoriasis yang berat. Terdapat beberapa macam pilihan terapi sistemik untuk psoriasis, di antaranya adalah isotretinoin oral dari golongan asam retinoat yang menghasilkan efektivitas cukup memuaskan untuk psoriasis eritroderma. ${ }^{4}$ Selain efektivitasnya, penting bagi kita untuk memahami efek samping yang ditimbulkan pada anak, misalnya risiko teratogenik, penutupan epifiseal secara dini, trombositopenia dan sebagainya.,

Berdasarkan catatan rekam medis RSUP Dr. Sardjito periode Januari 2011 sampai dengan Desember 2017 ditemukan 21 kasus baru psoriasis anak. Pada makalah ini akan dilaporkan 1 kasus psoriasis eritroderma pada anak perempuan 4,5 tahun yang diterapi dengan isotretinoin oral. Pembahasan ditekankan pada masalah penegakan diagnosis serta efektivitas dan efek samping terapi isotretinoin oral pada psoriasis eritroderma anak.

\section{KASUS}

Seorang anak perempuan berusia 4,5 tahun dengan keluhan kulit seluruh tubuh merah dan bersisik tebal. Ibu pasien mengatakan bahwa 2 bulan setelah lahir kulit tubuh anak kering, bersisik dan gatal. Semakin bertambah usia, kulit anak semakin merah dan sisik menebal. Kedua kelopak mata terlipat keluar dan bibir tertarik ke belakang, serta rambut sedikit rontok.

Pasien adalah anak tunggal. Tidak terdapat hubungan keluarga antara ayah dan ibu. Pasien dilahirkan cukup bulan, spontan, pervaginam ditolong oleh bidan di Puskesmas. Saat lahir anak langsung menangis, tidak biru maupun sesak nafas. Berat badan lahir 2700 gram. Selama hamil, ibu kontrol antenatal rutin ke bidan, mendapat vitamin untuk kehamilan dan tidak ada riwayat sakit apapun. Tidak ditemukan riwayat gangguan tumbuh kembang serta pendengaran pada pasien. Riwayat terbungkus selubung serupa plastik pada waktu lahir disangkal. Keluhan serupa dan riwayat atopi pada orang tua juga keluarga dekat disangkal. Silsilah keluarga pasien dapat dilihat pada gambar 1 .

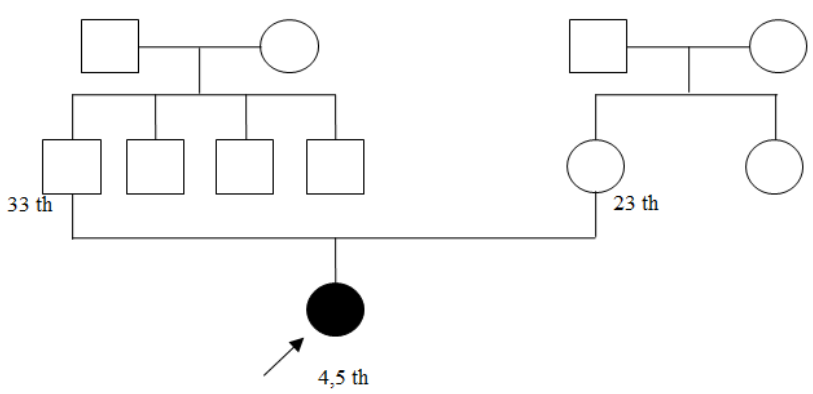

Gambar 1. Silsilah keluarga

Pemeriksaan fisik menunjukkan pasien sadar penuh, tanda vital dalam batas normal, berat badan $13 \mathrm{~kg}$, tinggi badan $98 \mathrm{~cm}$ dengan kesan status gizi cukup. Pemeriksaan paru, jantung, abdomen, dan saraf dalam batas normal. Kedua mata ektropion dan bibir eklabium. Pada kulit seluruh tubuh tampak eritematosa ditutupi skuama putih melekat berlapis tebal (gambar 2). Kedua puluh kuku jari tangan dan kaki tampak onikodistrofi. Tidak didapatkan keterbatasan gerak sendi maupun deformitas pada jari tangan dan kaki.

Berdasarkan anamnesis dan pemeriksaan fisik, diagnosis banding yang diajukan adalah psoriasis eritroderma, eritroderma iktiosis kongenital, iktiosis lamelar, dan sindrom Netherton. Pemeriksaan rambut kepala, alis, dan kelopak mata secara mikroskopik tidak ditemukan kelainan. Kadar serum IgE $>1000$ kUI/L. Pemeriksaan histopatologik menunjukkan epidermis tampak parakeratosis lamelar, hiperplasi pseudoepiteliomatosa, agranulosis, dan abses korneal yang berisi neutrofil (mikroabses Munro). Pada dermis tampak sebukan sel radang limfosit perivaskuler dan periapendikuler (gambar 3). Kesimpulan pemeriksaan histopatologi tersebut menyokong psoriasis eritroderma. Berdasar hasil pemeriksaan histopatologi, diagnosis kerja pada kasus ini adalah psoriasis eritroderma. 

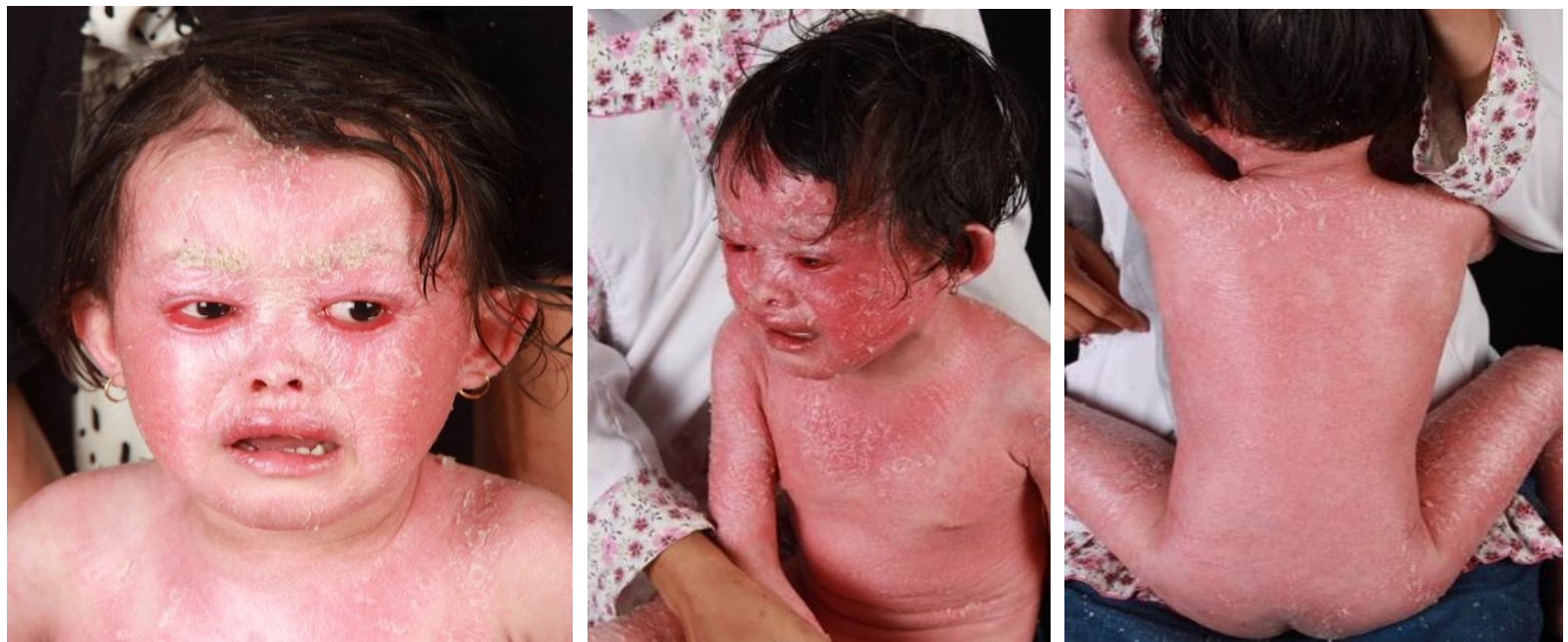

Gambar 2. Lesi kulit sebelum terapi isotretinoin oral
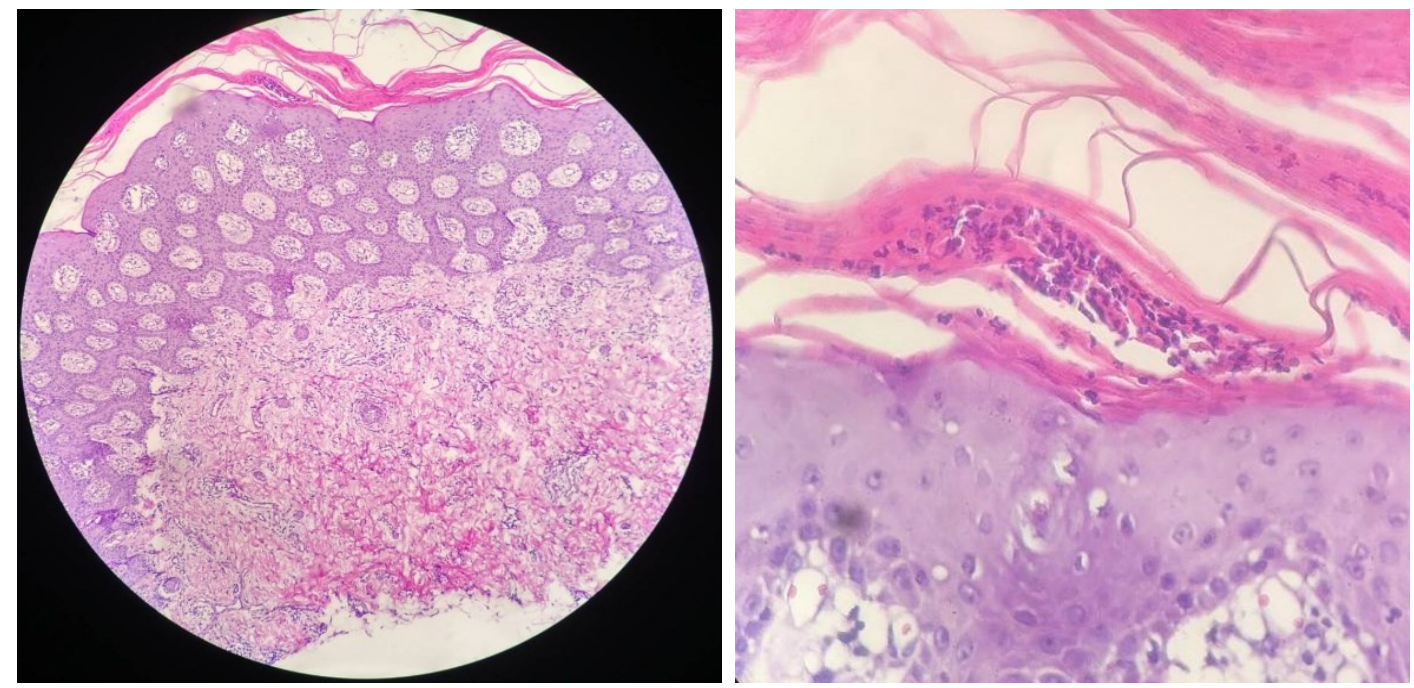

Gambar 3. [Kiri] Pemeriksaan histopatologi menunjukkan pada epidermis tampak parakeratosis lamelar, hiperplasia pseudoepiteliomatosa, agranulosis, dan abses di korneal yang berisi neutrofil (mikroabses Munro). Pada dermis tampak sebukan sel radang limfosit perivaskuler dan periapendikuler (H\&E, x40). [Kanan] Abses di korneal yang berisi neutrofil (mikroabses Munro) (H\&E, x400).

Hasil pemeriksaan laboratorium untuk darah perifer lengkap, fungsi hati dan ginjal, serta profil lipid dalam batas normal. Terapi yang diberikan adalah softgel capsule isotretinoin $10 \mathrm{mg} / \mathrm{hari}$, lotion Atopiclair ${ }^{\mathbb{B}}$ yang dioleskan ke seluruh tubuh dua kali sehari, dan mandi berendam dalam air yang diberi bubuk soda $(350 \mathrm{mg}$ bubuk soda/85 liter air) dua kali sehari selama 15 menit. Terapi ektropion yang diberikan adalah Cendo lyteers ${ }^{\circledR}$ yang diteteskan 6 kali sehari pada kedua mata. Pada hari ke-14 pasca terapi terdapat perbaikan pada lesi kulit pasien. Skuama putih berlapis tebal sudah berkurang serta ektropion dan eklabium membaik (gambar 4). Tidak didapatkan keluhan lain. Dilakukan pemeriksaan laboratorium darah perifer lengkap, fungsi hati dan ginjal, serta profil lipid. Hasil pemeriksaan dalam batas normal kecuali terdapat penurunan trombosit menjadi $81.000 / \mu \mathrm{L}$ dari sebelumnya $237.000 / \mu \mathrm{L}$ (normal: $150.000-450.000 / \mu \mathrm{L}$ ). Mean platelet volume (MPV) pada pemeriksaan pertama sebesar 6,37 fl dan yang kedua sebesar $8 \mathrm{fl}$ (normal: 7,2 $10,4 \mathrm{fl}$ ). Terapi isotretinoin dihentikan sedangkan terapi topikal dilanjutkan. Pada hari ke-28 dan ke-42 pasca penghentian terapi isotretinoin trombosit meningkat berturut-turut menjadi $150.000 / \mu \mathrm{L}$ dengan MPV 6,9fl dan $178.000 / \mu \mathrm{L}$ dengan MPV 6,9fl. Mulai hari ke-28 isotretinoin diberikan kembali dengan dosis $10 \mathrm{mg} / 3$ hari. 

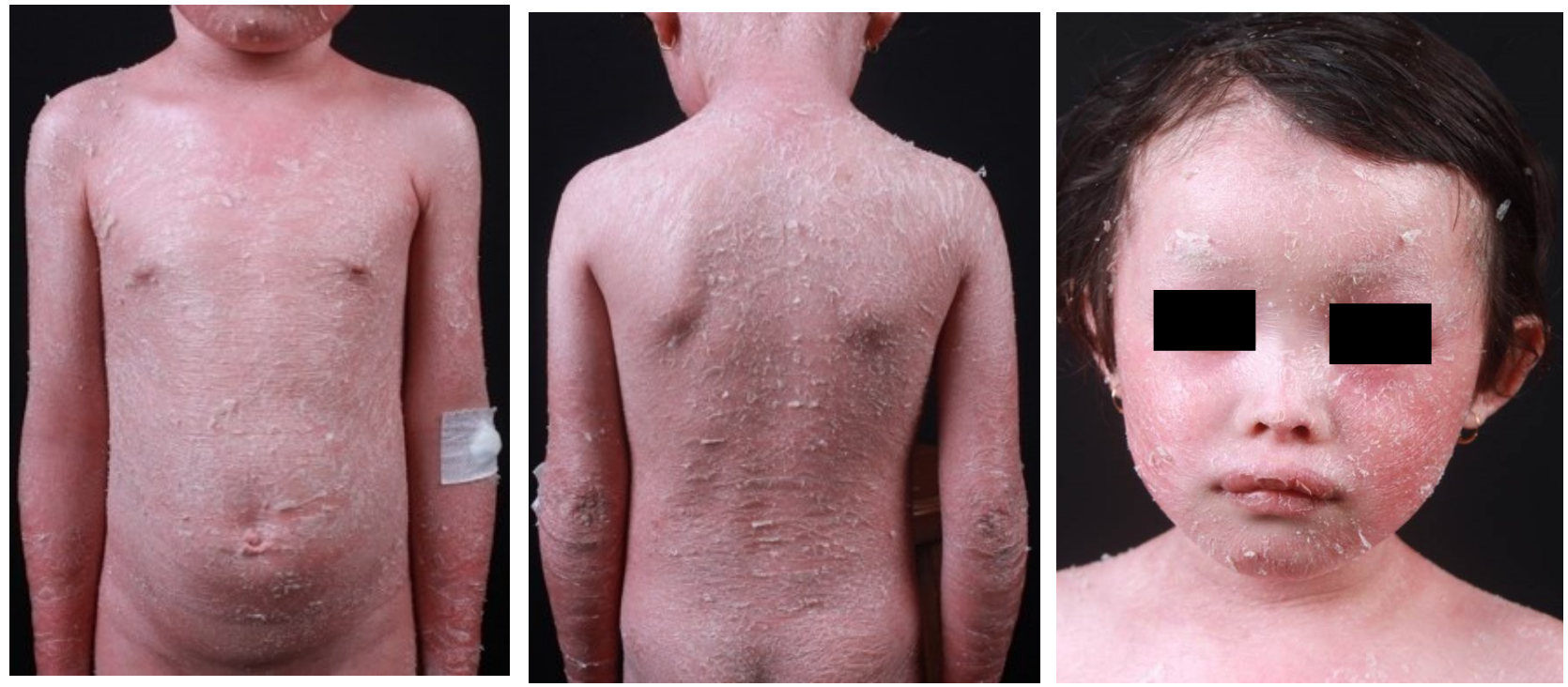

Gambar 4. Perbaikan lesi kulit setelah terapi isotretinoin oral $10 \mathrm{mg} /$ hari selama 14 hari dan $10 \mathrm{mg} / 3$ hari selama 14 hari

\section{PEMBAHASAN}

Psoriasis merupakan salah satu penyakit eritroskuamosa yang sering terjadi pada anak. Insidens psoriasis anak mengalami peningkatan yang progresif dari 29,6:100.000 populasi pada tahun 1970-1974 menjadi 62,7 pada tahun 1995-1999. ${ }^{2,3}$ Varian psoriasis tersering pada anak adalah psoriasis tipe plak generalisata dan gutata. Psoriasis eritroderma merupakan varian psoriasis anak yang jarang terjadi, sering disertai dengan ektropion, eklabium, dan onikodistrofi. ${ }^{3,5}$ Berdasarkan awitan timbulnya manifestasi klinis, psoriasis anak dibagi menjadi 4, yaitu psoriasis infantil, psoriasis awitan awal, psoriasis anak dengan artritis psoriatika, dan psoriasis kongenital. ${ }^{4}$

Psoriasis susceptibility gene 1 (PSOR1) pada kromosom 6 dan PSOR2 pada kromosom $17 \mathrm{q}$ tepatnya mutasi pada alel human leucocyte antigen (HLA) haplotypes (HLA-Cw6, HLA-B13, dan HLA-B17) adalah gen yang diduga berperan penting dalam timbulnya psoriasis pada anak. Dikatakan bahwa beberapa gen tersebut bermutasi bersamaan yang kemudian akan mengaktivasi sel limfosit T helper (Th) dan Th17 sehingga terjadi psoriasis. ${ }^{4}$ Patogenesis psoriasis anak multifaktorial, tetapi belum semua teori dapat dijelaskan secara pasti. Pada psoriasis terjadi akselerasi dari siklus germinativum epidermis yang mengakibatkan proliferasi keratinosit dan vaskularisasi di kulit dengan pemendekan waktu merenovasi epidermis yang diperantarai oleh sel limfosit $\mathrm{T}^{5,6}$

Gambaran histopatologik psoriasis pada epidermis tampak parakeratosis, akantosis reguler, hilangnya stratum granulosum, dan elongasi reguler rete ridges dengan penebalan di area basal. Pada dermis sering tampak edema papila dan dilatasi kapiler. Infiltrasi sel radang yang terdapat pada dermis didominasi oleh limfosit. Gambaran patognomonik psoriasis adalah infiltrasi neutrofil dalam stratum korneum yang disebut dengan mikroabses Munro. Pada psoriasis eritroderma dapat ditemukan akantosis reguler dan dilatasi kapiler. ${ }^{7}$

Diagnosis banding psoriasis eritroderma pada anak adalah iktiosis kongenital resesif autosomal (autosomal recessive congenital ichthyosis, ARCI), yang terdiri atas 4 varian, yaitu eritroderma iktiosiformis kongenital (congenital ichthyosiform erythroderma (CIE)), iktiosis lamelar, iktiosis Herlequin, dan sindrom Netherton - serta beberapa sindrom iktiosis. Walaupun disebut kongenital, manifestasi klinis penyakit dapat timbul beberapa saat setelah lahir. ${ }^{8,10}$ Eritroderma iktiosiformis kongenital atau eritroderma iktiosiformis kongenital nonbulosa (non bullous congenital ichthyosiform erythroderma, NBCIE) adalah iktiosis yang ditandai dengan eritroderma dengan skuama putih berlapis tipis di atasnya tanpa bula, yang dapat disertai ektropion, eklabium, hipoplasi nasal, kartilago aurikula, dan alopesia berparut. Pada CIE terjadi mutasi pada salah satu gen $A L O X E 3 A L O X 12 B, A B C A 12$, CYP4F22, NIPAL4z, TGM1 pada lokus kromosom 12p11.2-q13. ${ }^{8,11}$ Iktiosis lamelar didefinisikan sebagai salah satu bentuk iktiosis berat dengan kelainan kornifikasi khas berupa skuama lebar berwarna cokelat tua berlapis generalisata disertai ektropion, eklabium, dan alopesia berparut. Manifestasi klinis tambahan lainnya yang dapat timbul adalah onikodistrofi, keratoderma palmoplantar dan berkurangnya kemampuan berkeringat. Pada iktiosis lamelar terjadi mutasi pada salah satu gen TGM1, NIPAL4z, ALOX12B, ABCA12 pada lokus kromosom 12p11.2-q13. ${ }^{8,12}$ Sindrom Netherton merupakan sindrom iktiosis yang memenuhi 3 hal sebagai berikut: (1) iktiosis 
linearis sirkumfleksa atau eritroderma iktiosiformis, (2) kelainan rambut trichorrhexis invaginata (pilli torti), dan (3) diatesis atopi. Gagal tumbuh dan perawakan pendek merupakan kelainan ekstrakutan yang sering menyertai sindrom Netherton. Pada sindrom Netherton terjadi mutasi pada gen SPINK5. ${ }^{8,10,13}$ Pemeriksaan histopatologik pada ARCI tampak hiperkeratosis dan akantosis pada epidermis. Stratum granulosum pada CIE dan iktiosis lamelar tampak normal atau sedikit meningkat, sedangkan pada sindrom Netherton akan hilang atau menurun. Pada dermis tampak edema papila dan infiltrat sel radang limfositik ringan yang menyebar dan perivaskuler. ${ }^{10,11}$

Pada kasus ditemukan kulit seluruh tubuh tampak eritematosa ditutupi skuama putih melekat di tengah dengan tepi terlepas yang berlapis tebal yang secara klinis dapat didiagnosis sebagai eritroderma atau iktiosis. Awitan timbulnya manifestasi klinis tersebut pada bulan kedua kelahiran merujuk pada psoriasis eritroderma dan ARCI. Kelainan tambahan berupa ektropion, eklabium dan onikodistrofi dapat terjadi pada psoriasis eritroderma, CIE, iktiosis lamelar, dan sindrom Netherton. Kadar serum IgE yang tinggi walaupun tanpa riwayat atopi dan tidak ada kelainan rambut secara mikroskopik masih belum dapat menyingkirkan diagnosis banding sindrom Netherton. Penemuan abses korneal yang berisi neutrofil yang disebut dengan mikroabses Munro pada hasil pemeriksaan histopatologik merupakan kunci utama yang menyokong diagnosis psoriasis. Dengan demikian secara klinikopatologik diagnosis psoriasis eritroderma pada pasien ini dapat ditegakkan.

Pengobatan psoriasis pada anak harus mempertimbangkan aspek tumbuh kembang anak. Psoriasis yang berat atau psoriasis eritroderma membutuhkan pengobatan sistemik. Salah satu pilihan terapi sistemik yang dapat diberikan pada psoriasis eritroderma pada anak adalah isotretionin dari golongan asam retinoat. ${ }^{14,15}$ Isotretinoin merupakan salah satu kelompok generasi pertama retinoat non-aromatik yang memunculkan efek biologis dengan cara mengaktivasi reseptor nuklear dan meregulasi transkripsi gen. Efek isotretinoin tersebut berperan dalam regulasi dan diferensiasi sel, antikeratinisasi, antiinflamasi, antiapoptosis, dan antiseboroik. ${ }^{15,16}$ Efek terapi istretinoin terhadap psoriasis ada 3, yaitu menghambat serta mengurangi diferensiasi dan hiperproliferasi keratinosit, ditambah dengan mencegah infiltrasi sel radang pada kulit (inhibisi kemotaksis neutrofil). ${ }^{17}$ Al-Shobaili dkk. (2007) dan Sofen dkk. (1984) melaporkan keberhasilan terapi isotretinoin dosis $0,75-1,75 \mathrm{mg} / \mathrm{kg} /$ hari pada psoriasis pustulosa generalisata setelah 1-3 minggu pengobatan. ${ }^{18,19}$ Beberapa studi dan laporan kasus lain melaporkan keberhasilan kombinasi terapi isotretinoin oral dengan psoralen dan ultraviolet A (PUVA) atau UVB pada psoriasis berat dengan dosis $0,4-2 \mathrm{mg} / \mathrm{kg} /$ hari. $^{20-22}$
Hal yang sangat penting untuk diperhatikan pada terapi isotretinoin adalah efek samping obat yang biasanya timbul pada terapi jangka panjang. Efek samping yang dapat terjadi antatra lain efek teratogenik, penglihatan kabur, penutupan epifisis prematur, inflammatory bowel disease, pankreatitis, hepatitis toksik, pseudotumor serebri, depresi, keinginan bunuh diri, leukopenia, trombositopenia, keilitis, serotik, mata dan hidung kering, fotosensitif, rambut rontok, dan hipertrigliseridemia. ${ }^{15,16}$ Efek samping hematologik jarang terjadi. Bila terjadi, kelainan yang sering didapatkan berupa leukopenia (neutropenia). Kelainan hematologik berupa trombositopenia jarang sekali dilaporkan. ${ }^{23}$ Pada penelusuran kepustakaan terdapat sekitar 5 kasus trombositopenia yang terjadi akibat terapi isotretinoin. ${ }^{24-26}$ Dikatakan trombositopenia bila hitung trombosit kurang dari $100.000 / \mu \mathrm{L}$ dan dapat timbul perdarahan spontan bila kurang dari $40.000 / \mu \mathrm{L} .^{24-26}$ Terdapat 3 hipotesis yang diungkapkan oleh Moeller dan Touma untuk menjelaskan trombositopenia yang terjadi, yaitu respons imun, respons non-imun, dan supresi sumsum tulang. Trombositopenia yang terjadi bergantung pada terapi isotretinoin yang diberikan. Setelah terapi dihentikan hitung trombosit akan kembali normal sehingga tidak diperlukan terapi tambahan untuk mengatasi hal tersebut. $^{27}$

Pada kasus, sebelum memulai terapi, dilakukan pemeriksaan laboratorium darah, fungsi hati dan ginjal, serta profil lipid. Hasil pemeriksaan tersebut dalam batas normal sehingga dapat diberikan softgel capsule isotretinoin $10 \mathrm{mg} /$ hari (dosis: $0,4-2 \mathrm{mg} / \mathrm{kg} / \mathrm{hr}$; berat badan $13 \mathrm{~kg}$ ). Pasien juga diberikan lotion Atopiclair ${ }^{\circledR}$ dan disarankan untuk mandi berendam air yang diberi bubuk soda. Pasien diminta untuk kontrol 14 hari kemudian.

Pada saat kontrol terdapat perbaikan yang memuaskan pada lesi kulit pasien. Skuama putih berlapis tebal sudah berkurang serta ektropion dan eklabium membaik. Tidak didapatkan keluhan lain setelah 2 minggu terapi. Fungsi hati dan ginjal, serta profil lipid dalam batas normal. Pada pemeriksaan laboratorium darah perifer lengkap didapatkan trombositopenia. Tidak didapatkan tanda dan gejala perdarahan pada pasien. Trombositopenia tersebut kemungkinan besar disebabkan oleh efek samping isotretinoin. Terdapat 2 argumentasi yang dapat menyokong hal ini, yaitu (1) pasien hanya minum isotretinoin selama 14 hari pengobatan (konsumsi obat sistemik lainnya disangkal oleh pasien) dan (2) hitung trombosit berangsur membaik ketika terapi isotretinoin dihentikan. Walaupun memberikan hasil yang memuaskan dalam 2 minggu, terapi isotretinoin dihentikan sementara untuk mencegah timbulnya perdarahan yang akan membahayakan jiwa pasien. Terapi isotretinoin dilanjutkan dengan pengurangan dosis terapi ketika nilai trombosit pasien sudah kembali dalam batas normal. 


\section{SIMPULAN}

Telah dilaporkan 1 kasus psoriasis eritroderma yang mirip iktiosis herediter pada anak perempuan berusia 4,5 tahun yang diterapi isotretinoin oral. Diagnosis ditegakkan berdasarkan pemeriksaan klinis dan histopatologi. Didapatkan perbaikan klinis setelah diterapi isotretinoin selama 14 hari. Pada evaluasi hari ke-14 didapatkan trombositopenia yang kemungkinan besar disebabkan oleh pemberian isotretinoin. Terapi isotretinoin dihentikan sementara agar tidak membahayakan jiwa dan dilanjutkan dengan pengurangan dosis terapi ketika nilai trombosit pasien sudah kembali dalam batas normal. Perlu pemantauan ketat dan evaluasi laboratorium rutin pada pemberian isotretinoin oral pada psoriasis eritroderma anak, sehingga apabila ditemukan kelainan dapat segera dilakukan tatalaksana yang tepat.

\section{DAFTAR PUSTAKA}

1. Lysell J, Tessma M, Nikamo P, Wahlgren CF, Stahle M. Clinical characterisation at onset of childhood psoriasis: A cross sectional study in Sweden. Acta Dermatol Venereol. 2015;95:457-61.

2. Moll E, Chang MW, Strober B. Psoriasis in adults and children: Kids are not just little people. Clin Dermatol. 2016;1:1-17.

3. Bhutto AM. Childhood psoriasis: A review of literature. J Pakistan Assoc Dermatol. 2011;21:190-7.

4. Busch AL, Landau JM, Moddy MN, Goldberg LH. Pediatric psoriasis. Skin Therapy Lett. 2012;17:5-7.

5. Salleras M, Sanches-Regana M, Umbert P. Congenital erythrodermic psoriasis: Case report and literature review. Pediatr Dermatol. 1995;12:231-4.

6. Scott RB, Surana R. Erythrodermic psoriasis in childhood. Am J Dis Child. 1968;116:218-21.

7. Kumar P, Thomas J, Dineshkumar D. Histology of psoriatic erythroderma in infants: Analytical study of eight cases. Indian J Dermatol. 2015;60:213-6.

8. Oji V, Tadini G, Akiyama M, Bardon CB, Bodemer C, Bourrat E, dkk. Revised nomenclature and classification of inherited ichthyoses: Results of the first ichthyosis consensus conference in Soreze 2009. J Am Acad Dermatol. 2010;63:607-41.

9. Takeichi T, Akiyama M. Inherited ichthyosis: Nonsyndromic forms. J Dermatol. 2016;43:242-51.

10. Yoneda K. Inherited ichthyosis: Syndromic forms. J Dermatol. 2016;43:252-63.
11. Akiyama M, Sawamura D, Shimizu H. The clinical spectrum of nonbullous congenital ichthyosis erythroderma and lamellar ichthyosis. Clin Exp Dermatol. 2003;28:23540.

12. Suraiyah, Soedibyo S, Boediardja SA. Iktiosis lamelar pada anak dengan riwayat bayi kolodion. Sari Pediatri. 2007;9:32-8.

13. Furio L, Hovnanian A. 1. Netherton syndrome - defective kallikrein inhibition in the skin leads to skin inflammation and allergy. Biol Chem. 2014;395:945-58.

14. Lara-Corrales I, Xi N. Childhood psoriasis treatment evidence published over the last 5 years. Rev Rec Clin Trials. 2011;6:36-43.

15. Patton TJ, Ferris LK. Systemic Retinoid. In: Wolverton SE. Comprehensive Dermatologic Drug Therapy. Edisi ke-3. Toronto: Elsivier Saunders; 2013. p. 252-68.

16. Tahir CM. Efficacy and adverse effects of systemic isotretinon therapy. J Pakistan Assoc Dermatol. 2011;21:38-42.

17. Akyol M, Ozcelik S. Non-acne dermatologic indications for systemic isotretinoin. Am J Clin Dermatol. 2005;6:175-84.

18. Al-Shobaili H, Al-Kenaizan S. Childhood generalized pustular psoriasis:Successful treatment with isotretinoin. Pediatr Dermatol. 2007;24:563-4.1

19. Sofen HL, Moy RL, Lowe NJ. Treatment of generalised pustular psoriasis with isotretinoin. Lancet. 1984;7:40.

20. Fritsch PO. Retinoids in psoriasis and disorders of keratinization. J Am Acad Dermatol. 1992;27:S8-14.

21. Ansty A, Hawk JLM. Isotretinoin-PUVA in women with psoriasis. Br J Dermatol. 1997;136:798-800.

22. Mortazavi H, Khezri S, Hosseini H. Khezri F. Vasigh M. A single blind randomized clinical study: The efficacy of isotretinoin plus narrow band ultraviolet $B$ in the treatment of psoriasis vulgaris. Photodermatol Photoimmunol Photomed. 2011;27:159-61.

23. Rademaker M. Adverse effects of isotretinoin- A retrospective review of 1743 patients started. Australas J Dermatol. 2010;51:248-53.

24. Brito MFM, Galindo JCS, Santos JB, Sant'Anna IP, Rosendo LHPM. Evaluation of clinical adverse effects and laboratory alterations in patients with acne vulgaris treated with oral isotretinoin. Ann Bras Dermatol. 2010;85:331-6.

25. Ataseven A, Bilgin AU. Effects of isotretinoin on the platelet counts and the mean platelet volume in patients with acne vulgaris. Scientific World J. 2014;2014:1-4.

26. Garipardic M, Sasmaz S, Olgar S, Guler E. Neutropenia and thrombocytopenia in a patient used isotretinoin for acne vulgaris. Balikesir Health Sci J. 2013;1:77-8.

27. Moeller KE, Touma SC. Prolonged thrombocytopenia associated with isotretinoin. Ann Pharmacother 2003;37:1622-4. 